\title{
Government strategic planning: an integrative review of academic production
}

\section{Planejamento estratégico do governo: uma revisão integrativa da produção acadêmica}

\author{
Bernardo de Almeida Villanueva \\ Master in Public Planning and Governance \\ Federal University of Technology - Paraná (UTFPR) \\ E-mail: villanueva@alunos.utfpr.edu.br

\section{Anderson Catapan} \\ Post-Doctor in Management from Fernando Pessoa University \\ Federal University of Technology - Paraná (UTFPR) \\ E-mail: catapan@utfpr.edu.br
}

\section{ABSTRACT}

Strategic planning is a deliberative, disciplined approach to producing fundamental decisions and actions that shape and guide what an organization is, what it does, and why it does it. Although strategic planning comes first from the private sector, it can, in fact, lead to successful strategy implementation in the public sector. Public institutions need to implement a performance management system in order to provide better public service to citizens, to promote sustainable public policies, to ensure a transparent decision making process, to spend the public money in an efficient and accountable way, and to achieve measurable results in implementing strategies, programs and projects. The objective of this study is to verify what is being studied in the field of government strategic planning in the past five years, considering articles indexed in the Web of Science database. The study shows that the main topics of concern are related to urban and metropolitan planning, reform and budget cuts, and studies verifying the effectiveness of strategic planning in the public sector.

Keywords: government strategic planning, public sector, bibliographical review.

\section{RESUMO}

O planeamento estratégico é uma abordagem deliberativa e disciplinada para produzir decisões e acções fundamentais que moldam e guiam o que uma organização é, o que faz, e porque o faz. Embora o planeamento estratégico venha primeiro do sector privado, pode, de facto, conduzir a uma implementação bem sucedida da estratégia no sector público. As instituições públicas precisam de implementar um sistema de gestão de desempenho a fim de prestar um melhor serviço público aos cidadãos, promover políticas públicas sustentáveis, assegurar um processo transparente de tomada de decisões, gastar o dinheiro público de forma eficiente e responsável, e alcançar resultados mensuráveis na implementação de estratégias, programas e projectos. O objectivo deste estudo é verificar o que está a ser estudado no campo do planeamento estratégico 
governamental nos últimos cinco anos, considerando artigos indexados na base de dados da Web of Science. O estudo mostra que os principais temas de preocupação estão relacionados com o planeamento urbano e metropolitano, reformas e cortes orçamentais, e estudos que verificam a eficácia do planeamento estratégico no sector público.

Palavras-chave: planeamento estratégico do governo, sector público, revisão bibliográfica.

\section{INTRODUCTION}

With the contemporary multiplying uncertainties of governments, politicians and public managers are constantly faced by a recurrent problem: despite financial constraints and with scarce resources, they have to combine the delivery of efficient public services with economic development and democratic quality (IGLESIAS ALONSO, 2014).

Strategic thought and action are increasingly important to the continued viability and effectiveness of governments, public agencies and non-profit organizations of all sorts. Without strategic planning it is unlikely that these organizations will be able to meet successfully the numerous challenges that they frequently face (BRYSON, 1988).

Strategic planning is a deliberative, disciplined approach to producing fundamental decisions and actions that shape and guide what an organization is, what it does, and why it does it. Strategic planning is not a substitute for strategic thinking, acting, and learning, or for leadership. Instead, strategic planning is a leadership tool meant to enhance strategic thinking, acting, and learning. Strategic planning can produce several benefits, but there is no guarantee that it will do so (BRYSON, 2015).

When strategic planning arrived on the scene in the mid-1960s, corporate leaders embraced it as "the one best way" to devise and implement strategies that would enhance the competitiveness of each business unit. Planning systems were expected to produce the best strategies as well as step-by-step instructions for carrying out those strategies so that the doers, the managers of businesses, could not get them wrong (MINTZBERG, 1994). 
Since around 1980, public use of strategic planning has skyrocketed. This experience and a growing body of literature have indicated that strategic planning approaches, when adapted to public and purposes, can help these entities deal effectively with their often dramatically changing environments (BRYSON, 2015).

The public sector has been under pressure for a long time to become more efficient, effective and responsive. Many have felt that the adoption of business practices would help to accomplish that. One tool borrowed from business has been strategic planning (VAN RAVENSWAY and HAMLIN, 2015).

Strategic management as a private sector model displays certain incompatibilities with the structural and procedural characteristics of the public sector as well as with the political context. Strategic management relies heavily on efficiency, effectiveness and flexibility to achieve competitive advantage, and this notion portrays conflicts/disparities with the characteristics of the public sector/policy (UNAL, 2013).

Practicing public managers, who might not be directly involved in public policy decisions, should know that their efforts to strategically plan for their organizations is neither a waste of time nor resources, but can, in fact, lead to successful strategy implementation. This is an indication that formal strategic planning is beneficial to public organizations (ELBANNA et al., 2016).

Public institutions need to implement a performance management system in order to provide better public service to citizens, to promote sustainable public policies, to ensure a transparent decision making process, to spend the public money in an efficient and accountable way, and to achieve measurable results in implementing strategies, programs and projects (PROFIROIU et al., 2013).

The objective of this study is to verify what is being studied in the field of government strategic planning in the past five years considering articles indexed in the Web of Science database.

Having in perspective the facts discussed above, this study aims to answer the following question: What are the main topics being studied in the field of government strategic planning? 


\section{THEORETICAL BACKGROUND}

As a term, 'strategy'-like many concepts-has a complex structure that takes shape and gains meaning according to the perspective it is seen from, and which is formulated within different models (plan, position, perspective, tactic). Thus, by its structure, the definitions on strategy show diversity, and sometimes irony; that is to say, although strategy is defined in a certain manner in some cases, it can also be used with a different meaning (UNAL, 2013).

Planning suggests clear and articulated intentions, backed up by formal controls to ensure their pursuit, in an environment that is acquiescent. In the planned strategy, leaders at the center of authority formulate their intentions as precisely as possible and then strive for their implementation. To ensure this, the leaders must first articulate their intentions in the form of a plan, to minimize confusion, and then elaborate this plan in as much detail as possible, in the form of budgets, schedules and so on, to pre-empt discretion that might impede its realization (MINTZBERG E WATERS, 1985).

Strategic planning/management, strategy creation and implementation and strategy as a term/concept are phenomena, which not only differ, but gain meaning according to the structure in which they develop (UNAL, 2013).

In the strict sense, strategic management is a concept that has emerged as a form of management of the private sector organizations in order to achieve competitive advantage, and is also adapted to the public sector organizations (UNAL, 2013).

Strategic planning can help Government and non-profit organizations to think strategically; clarify future direction; make today's decisions in light of their future consequences; develop a coherent and defensible basis for decision making; exercise maximum discretion in the areas under organizational control; solve major organizational problems; improve performance; deal effectively with rapidly changing circumstances; build teamwork and expertise (BRYSON, 1988).

Strategic planning is not a single thing, but is instead a set of concepts, procedures, and tools that must be carefully tailored to situations if desirable outcomes are to be achieved (BRYSON, 2015). 
Strategic planning for communities comprises a set of concepts, procedures, and tools that are broader than those of more traditional urban planning. Community strategic planning is typically viewed as an important precursor of comprehensive or spatial strategic planning, since it tends to focus on the community holistically as an integrated social, economic, political, and environmental system. Strategic planning thus can help frame and articulate the broad strategies that show how land use, transportation, housing, the environment, education, economic development, health, social services, and urban branding and marketing efforts, among others, might be linked; what key points of leverage and priorities among specific strategies might be; how progress might be measured and communicated; and what lessons might be learned from ongoing implementation (BRYSON, 2015).

Strategic planning has the potential to enable cities to weather the effects of fiscal crises. City officials can use the information gathered though internal and external scanning to implement fiscal policy changes that can minimize their governments' exposure to external fiscal shocks and to experiment with alternative service delivery arrangements that generate cost savings (JIMENEZ, 2013).

Linking strategic plans to budgets allows cities to focus on core services, and reduce expenditures for nonessential programs. Strategic plans can also provide a framework for operations, facilitating closer cooperation and coordination among managers and workers in preventing the further deterioration in the fiscal condition of their organization (JIMENEZ, 2013).

When done well, strategic planning offers a number of benefits. Advocates usually point to six main potential benefits. The first is promotion of strategic thinking, acting, and learning. The second is improved decision making, while the third is enhanced organizational effectiveness, responsiveness, and resilience. The fourth is enhanced organizational legitimacy. The fifth is increased effectiveness of broader societal systems to which public and nonprofit organizations contribute. Finally, strategic planning can directly benefit the organization's people by helping them better perform their roles, meet their 
responsibilities, and enhance teamwork and expertise. There is no guarantee, however, that these benefits will be achieved. For one thing, strategic planning is simply a set of concepts, procedures, and tools that must be applied wisely to specific situations. Also, when they are applied wisely, as it was discussed before, there is no guarantee of success (BRYSON, 2015).

A key feature of the conventional approach to strategic planning is that the formulation and implementation of plans are sequential activities. Strategy is first deliberately formulated and only then it is put into place. Nevertheless, while this may suggest that strategic management is a sequential activity, each of the different stages of the planning process is not typically separate in practice, and organizations invariably evince emergent as well as deliberate or planned strategies concurrently (ELBANNA et al., 2016).

\section{METHODOLOGY}

The current study can be defined as a bibliographical research, in this case exclusively based on scientific articles.

The main advantage of bibliographical research is that it allows the researcher to cover a much wider range of phenomena than the one that he could research directly. This advantage becomes particularly important when the research problem requires data widely scattered throughout space (GIL, 2002).

A search was conducted in December 2017 in the Web of Science database, using the term "Strategic Planning" and, then, the following filters were applied: publications between the years of 2013 e 2017, only articles, area of knowledge "Public Administration". This search, with the correspondent filters resulted in a total of 66 articles, which were analyzed to verify what their main subarea of study and what their geographical area of study are.

\section{RESULTS AND DISCUSSION}

Among the 66 results found on Web of Science under the defined criteria, there are articles from many countries and with several approaches. 
Europe is the region with the biggest production of articles in the last five years.

In Belgium there is a big amount of articles considering the size of the country. There are articles about urban planning, such as the one by BOUSSAUW and BOELENS (2015), which focuses on an important discrepancy that occurs between the discourse conducted by the planners and the real developments that happen in the field.

Budget is also a topic studied (GEORGE et al., 2017), in an article that correlates performance and budget, in the form of politicians' preferences for spending and reform, with positive correlation between factors.

In Belgium, the effectiveness and quality of strategic planning in public organizations is another topic studied. In an article, GEORGE, 2017, concludes that strategic planning is more than a fad and can contribute to positive outcomes, but this contribution is contingent upon the behavior underlying the strategic planning process. In another one, (GEORGE et al., 2016) investigates and confirms the assumption that strategic planning strengthens strategic decision quality, if a systematic approach is taken and if top policy-makers and managers, as well as lower-level staff and external stakeholders, are involved.

In Italy, LONGO and ROTOLO (2016) study strategic awareness and its implications for strategic planning in public organizations, arriving to some relevant drivers that can promote strategic awareness. PERCOCO (2016) studies the collective action in Italian cities, which predicts that collaboration among institutions is more likely to occur in areas with larger social capital stock and where public bodies share a common history of collaboration, confirming that in these cases there is an increased probability of the city adopting a strategic plan.

The English production in the field appears with an article by HOLMAN and THORNLEY (2015), which explores the tensions in metropolitan level governance between strategic planning and desires for political decentralization, which has reached the conclusion that strategic planning and decentralization are not really a match that works. 
Another English article, by BIANCHI et al. (2017) explores different contexts for the role of public sector decision-making, showing that simultaneous achievement of key outcomes, service quality dimensions, and governance principles may not be feasible, meaning that politicians may need to accept that they are not determining the achievement of optimal outcomes in a predictable cause-and-effect chain, but rather shaping the emergence of acceptable outcomes in a difficult- to-predict set of relationships.

French authors FAVOREU et al. (2016) look into the strategy formulation processes in the public sector and the type of strategic approach that best matches the characteristics of this sector, coming to a complex strategic process that combines and alternates rational, collaborative and political decision-making logics, and a planned and incremental development.

In the Netherlands, LEVELT and JANSSEN-JANSEN (2013) study the governance networks in the Amsterdam region, concluding that city-region governance needs to involve not only government interests but also interests of market players and NGOs to become effective, efficient, and legitimate and that national policy interference is to a large extent incompatible with it.

Regional development is the theme of a study by HARTMAN and DE ROO (2013) focusing on the nonlinear development regions that reinvent themselves by adapting to processes that drive spatial change, deviating from past development trajectories.

When it comes to Spain, IGLESIAS ALONSO (2014) focuses on the way in which the use of Strategic Planning entails a trade-off between urban and economic development and democracy, also arguing that it is the interaction and combination of institutional issues, communal, social and political resources that determine the paths and developments of local government innovations.

RUANO (2015) explores the case of the city of Móstoles, which is an example of a city that undertook a process of strategic planning, based on the active participation of its citizens, to develop the city in the long term. This planning process has become a tool for transforming the administrative culture of 
the City Hall and for government accountability to citizens regarding the degree to which the objectives of the plan are fulfilled and its political performance.

Eastern European countries also have some production in the field of government strategic planning. In Estonia, there is an article about performance budgeting reform by RAUDLA (2013), reform which was outsourced to private sector organizations. The study concluded that such a reform strategy can run into serious problems, including fragmented and inconsistent reform plan, limited learning, and high transaction costs, that have undermined the democratic legitimacy of the reform.

Author BARATI-STEC (2015) works with the strategic planning for municipalities in Hungary and concludes that while strategic planning improves the performance of local governments, special aspects, such as the financial dependency of municipalities, focus on daily operation and on short-term results and enhanced need of institutional and personal capacity management must be solved during the process.

In Poland, there is an article by SZTANDO (2017) that focuses on what motivates the implementation of strategic planning in Polish small towns, with conclusions that the motivation for strategic planning in more than one third of the small towns is low and that the motive for obtaining means from the EU funds was and is motivating strongly for at least $68.6 \%$ of these authorities when discussing planning, which is a short-term motive.

The production of articles in Romania focuses on the performance of government (PROFIROIU et al., 2013), with conclusions that a few things should be improved in the planning system of the country, and strategic planning for public management reform (HINTJEA et al., 2015), concluding that over $70 \%$ of strategic planning efforts are done because it is a mandatory condition for accessing EU funds and being the main issue implementation, monitoring and evaluation of the strategic planning.

Romania based authors SZABO et al. (2016) study transparency and its correlation with the improvement of government, concluding transparency is 
dependent on a strong political leadership and needs to be integrated into the organizational strategic planning in order to be effective.

PETREA et al. (2013) study place branding in some Romanian cities as an efficient management tool for local governments, concluding it is still a process at its beginning in the country.

Russia is the subject of study by CAROL et al. (2015), who work with strategies for regional development and cooperation between macro-areas instead of competition, and OLGA (2015) who works with the strategic urban planning in two municipalities concluding that that for an effective development of strategic planning in Russia, it is necessary to solve questions related to its legal regulation and methodical maintenance.

VLADIMIR (2016) explores the need the Russian Federal Government has to improve regulation through the creation of laws in order to improve the quality of public administration, which shall become the Federal law on performance management of public authorities, considering strategic planning, objectives and results of development.

Urban agglomerations is the theme studied by VULFOVICH (2016), comparing Russian agglomerations with other European and North American examples and mentioning that these agglomerations possible motors of growth and development and elaboration of strategies for them could be the starting point in the recovery of the economy and society in Russia.

LARIONOV (2015) has regional cooperation as a theme, questioning if closely-tied regions should, in the long run, form a centralized system of administrative bodies, compressing their budgets into one, and constructing unified social programs. The author concludes such centralization has its limits, and instead of "rough" centralization, more sophisticated procedures should be elaborated to provide the sustainable development of closely-tied regions.

In Turkey, DEMIRKAYA (2015) works in an evaluation of strategic planning in the Turkish public sector, with something more related to budget in the country, but which has been gaining importance in the past few years, with concepts such as corporate objectives, targets, participation, transparency, 
accountability, results and performance-oriented perspective starting to consolidate.

UNAL (2013) evaluates how far Public Organizations can be strategically managed, concluding that a strategy and strategic management model specific to the public sector can be set forth, but due to the characteristic of the public sector, this model, as presently implemented by the institutions, cannot go beyond being a strategic plan consisting of an abstract and outline expressions, which is far from concrete intermediate goals.

In North America, the place of birth of strategic planning, there are articles both from the United States and Canada. In Canada there is an article about a budget reform by LEVASSEUR and ROUNCE (2017), focusing on a new form of budgeting expected to generate billions in savings and the alignment of cuts with public policy priorities.

The implementation of strategic planning is also a topic of a study in Canada (ELBANNA et al., 2016), with an analysis of insights into strategy implementation and variables which may influence its success.

Two articles by MARLAND (2017) study the strategic management in terms of communications in the Canadian government - one of them focusing on communication plans and the other one on the centralization of communication control in the government.

Studies in the United States of America are abundant. Both JIMENEZ (2013), PERNSTEINER et al. (2016) and PASHA and POISTER (2017) explore themes related to budget and fiscal crisis. The first article relates strategic planning with the capability of reducing negative effects of fiscal crises and the second article discusses how strategic decisions on the definition of budgets can be used for political spectacles, in this case against a rise required by teachers. The third article studies how traffic agencies in small cities dealt with the recession, concluding that they placed greater emphasis on performance measurement practices and used a blended approach of formal strategic planning and logical instrumentalism. 
Urban planning is a topic of study by VAN RAVENSWAY and HAMLIN (2015) and KWON et al. (2013), being the first study focused on community long term planning on municipalities and the second one focused on the development of a framework for measuring cities' use of strategic planning, that includes factors related to form of government, community wealth, and other community attributes.

JUNG and LEE (2013) investigate the effects of goal properties and strategic planning capacity and its effects on government agency performance, concluding that goal related attitudes and activities can make crucial contributions to the enhancement of organizational performance. POISTER et al. (2013) study the effect of strategic planning and logical incrementalism on the performance of small and medium-size urban transit agencies, concluding that strategic planning, whether on its own or combined with logical incrementalism, has a positive effect on some dimensions of performance.

There are some articles that work with multiple countries in Europe. HAMMERSCHMID and LÖFFLER (2015) compare the use of performance management in European central governments in a survey conducted in 17 countries. The data confirms that performance management has made its way into European central governments and continues to constitute a major reform trend.

JUNJAN (2015) investigates the current results published in the scientific literature with respect to strategy development in local governments within the European Union (EU). The results suggest that the efforts to analyze the strategy development in local governments are primarily associated to the urban planning field and to a lower extent to public administration journals.

A comparative analysis regarding sustainable development plans from the European Union, the Mediterranean and Slovenia, is conducted by DEŽELAN and MAKSUTI (2014). The results reveal that the major differences between the assessed strategies are present in the sophistication of the theoretical bases and the integration of three main pillars of sustainable development (i.e. 
environmental, economic and social). A common weakness among them is in terms of implementation of the plans.

RUDLA et al. (2017) explore how European governments have reacted during the most recent crisis, focusing on whether rationally oriented management approaches are associated with targeted and efficiency cuts rather than across-the-board cuts, using data from 19 countries. The findings include several rationally oriented approaches, such as the use of strategic planning, are positively associated with the use of targeted and efficiency cuts.

Other regions of the world also have production in the area. In Australia there are studies focused on different approaches. RYAN and HASTINGS (2015) focus on the adoption of indicators in local governments, mentioning that indicators are a powerful mechanism for enhancing democratic engagement, setting strategic priorities for public policy and service delivery, measuring progress towards a healthy and sustainable community, and encouraging social and behavioral change.

BUNKER (2015) works in the field of urban planning, discussing the planning of the city of Adelaide, where evidence shows that the plan is not tracking as proposed and more attention needs to be paid to short- and mediumterm prospects, and community involvement, particularly in strategic localities.

SAMSOM (2016) also works in the local level (urban planning), but approaching the need for more effective civic leadership, and in particular the role of mayors, who should promote robust local democracy based on a strong sense of community and local identity.

Finally MCMAHON and PHILLIMORE (2013) work with the planning in the level of States and Territories, showing that only a few states in Australia have strategic plans in place and proposing that there are three key strategic orientations for Australian state plans: to holistically manage, monitor and market government administration.

MALEKPOUR et al. (2017) study the relation between strategic planning and sustainable development in the case of the city of Melbourne, offering initial 


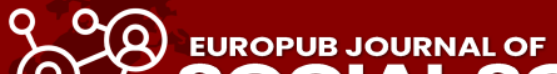

ingredients for a diagnostic tool to explore planning problems in the context of sustainable development.

Some other sources work with themes not exactly related to the government itself, but with agencies and other institutions related to it and even non-governmental organizations, exploring themes such as hospital management, human service, sports, fundraising and others.

\section{SYNTHESIS OF THE ARTICLES}

After an analysis of all articles, they were classified by type and by country of the study, in order to answer the question of this study, i.e., what are the main topics being studied in the field of government strategic planning?

A total of 19 articles are not directly related to government strategic planning, leaving a total of 47 articles to be analyzed. Table 1 displays the articles by main subject of study, showing that out of a total of 47 articles directly related to government strategic planning, 12 focus on urban planning and municipalities, 8 focus on topics related to budget, cost reductions and reform, and 6 focus on the effectiveness of strategic planning in the public sector, these being the three main topics of study.

Table 1: Main topics of articles

Main theme Quantity

Analysis of literature $\quad 1$

Budget / reform 8

Decision making in public service 1

Effectiveness of strategic planning

Goal setting x performance 1

Governance networks $\quad 1$

Indicators and democratic engagement 1

Motivation for strategic planning 1 


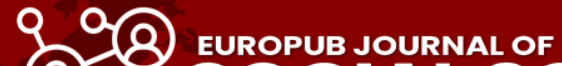

Performance law

Place branding

1

Regional development

3

Strategic awareness

Strategic plan adoption

1

Strategic planning implementation3

Strategical communications 2

Sustainable development plans 2

Transparency 1

Urban / metropolitan planning 12

Source: the author

When it comes to which country is the subject of study, of the 47 articles directly related to government strategic planning, there is not a big concentration in one country. The United States comes first, with a total of 7 articles, followed by Australia and Russia, with 5 articles and Belgium, Canada and Romania, with 4 articles each, as shown on Table 2. A total of 4 articles consider the entire Europe as an area of study.

Table 2: Production by Country

Country Articles

Australia 5

Belgium 4

Canada $\quad 4$

England / UK2

Estonia 1

Europe $\quad 4$

France $\quad 1$ 


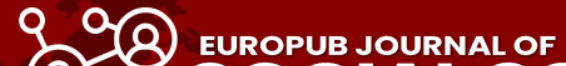

Hungary 1

Italy 2

Netherlands 2

Poland 1

Romania 4

Russia 5

Spain 2

Turkey 2

United States7

Source: the author

Considering the size and population of Romania and Belgium, it is safe to say they have an outstanding production of articles in the past five years.

Considering regions, Europe is the main region where articles are being produced, with a total of 31 articles, followed by North America, with 11 and Oceania with 5 .

\section{CONCLUSION}

This study aims at verifying what the main topic of study in articles indexed in the Web of Science database produced from 2013 to 2017 was, having as its main topic government strategic planning.

The methodology used was bibliographical research, which allowed getting information on the topic of study in a worldwide basis.

Data was gathered considering certain filters established which led to a total of 66 articles, analyzed in terms of main topic of study within the area of government strategic planning and in which country and region the topic of study was conducted. 
Results show that the main topics of study were urban planning and related themes, showing that the local issues are important subjects of study in the area, probably because this kind of study is more relatable to the community in general. Budget, cuts and reform came second, which can be understood as a reflex of the recent crisis is many regions of the world, leading governments to the need to readapt their expenses to new realities.

Finally, the effectiveness of strategic planning in the government came third as a theme, which can be interpreted as the need the scientific community feels to evaluate if a tool which is typically from the private sector can actually have successful results in the public sector.

When it comes to regions and countries, the United States appeared as the main producer of articles, which can be explained both by the fact that the country has a big tradition in adopting strategic planning, but also by the fact the language being used for the search is English.

The fact that among the articles directly related to government strategic planning the production is only from Europe, Oceania and North America requires attention. Among the whole sample there are also four articles produced in Brazil and more European and North American Articles, which shows there is no recent production in English in regions like Asia, Africa and Latin America (except from Brazil). This could imply government strategic planning is only being studied in regions where it is already a strong management tool.

Further studies could deal with topics such as why there is no production of articles in the regions mentioned above or establish a correlation between what is indexed in the Web of Science database and the production in databases in other languages, like Portuguese and Spanish, such as SciELO. 


\section{REFERENCES}

AFONSO, R. W. et al. An Assessment of the Adoption of the BSC by State Court of Auditors. CADERNOS GESTAO PUBLICA E CIDADANIA. JAN-JUN 2015. Volume 20. Edition 66. Pages 3-18.

BARATI-STEC, I. Strategic planning in Hungarian municipalities. TRANSYLVANIAN REVIEW OF ADMINISTRATIVE SCIENCES. 2015. Pages 5-14.

BIANCHI, C. et al. Applying a Dynamic Performance Management Framework to Wicked Issues: How Coproduction Helps to Transform Young People's Services in Surrey County Council, UK. INTERNATIONAL JOURNAL OF PUBLIC ADMINISTRATION. 2017. Volume 40. Edition 10. Pages 833-846. DOI 10.1080/01900692.2017.1280822

BOUSSAUW, K. ; BOELENS, L. Fuzzy tales for hard blueprints: the selective coproduction of the Spatial Policy Plan for Flanders, Belgium. ENVIRONMENT AND PLANNING C-GOVERNMENT AND POLICY. DEC 2015. Volume 33. Edition 6. Pages 1376-1393. DOI 10.1068/c12327

BRYSON, J. M. Strategic Planning for Public and Nonprofit Organizations, In International Encyclopedia of the Social \& Behavioral Sciences (Second Issue:), edited by James D. Wright, Elsevier, Oxford, 2015, Pages 515-521. DOI 10.1016/B978-0-08-097086-8.74043-8.

BUNKER, R. Can We Plan Too Much? - The Case of the 2010 Metropolitan Strategy for Adelaide. AUSTRALIAN JOURNAL OF PUBLIC ADMINISTRATION. SEP 2015. Volume 74. Edition 3. Pages 381-389. DOI 10.1111/1467-8500.12099 CAMPBELL, C. Reducing Waits for VHA Services Through Use of Tools of Governance. HUMAN SERVICE ORGANIZATIONS MANAGEMENT LEADERSHIP \& GOVERNANCE. 2016. Volume 40. Edition 1. Pages 74-85. DOI $10.1080 / 23303131.2015 .1054541$

CAROL, L. et al. The outward dimension in Russia's regional development strategies: a mapping of prospective cooperation. VOPROSY GOSUDARSTVENNOGO I MUNITSIPALNOGO UPRAVLENIYA-PUBLIC ADMINISTRATION ISSUES. 2015. Edition 5. Pages 93-110.

Centenaro, A. et al. The Future of Nossa Senhora hospital is in Your Hands. ADMINISTRACAO PUBLICA E GESTAO SOCIAL. APR-JUN 2017. Volume 9. Edition 2. Pages 130-134. DOI 10.21118/apgs.v1i2.1228

CLASEN, J. ; KOSLOWSKI, A. Unemployment and Income Protection: How do Better-Earning Households Expect to Manage Financially?. JOURNAL OF SOCIAL POLICY. JUL 2013. Volume 42. Edition 3. Pages 587-603. DOI $10.1017 /$ S004727941300007X 
CRONLEY, C. ; KIM, Y. K. The Path to Service Quality: The Mediating Role of Organizational Commitment on the Effects of Strategic Planning and Technology Access Within The Salvation Army. HUMAN SERVICE ORGANIZATIONS MANAGEMENT LEADERSHIP \& GOVERNANCE. 2014. Volume 38. Edition 1. Pages 74-88. DOI 10.1080/03643107.2013.828006

DA SILVA, A. K. et al. Strategic Situational Planning - PES: an bibliometric analysis of Brazilian scientific production. REVISTA DO SERVICO PUBLICO. APR-JUN 2017. Volume 68. Edition 2. Pages 365-387.

DEMIRKAYA, Y. Strategic planning in the Turkish public sector. TRANSYLVANIAN REVIEW OF ADMINISTRATIVE SCIENCES. 2015. Pages 15-29.

DEZELAN, T. ; MAKSUTI, A. Towards our common future: comparative assessment of the sustainable development strategies of the European Union, the Mediterranean and Slovenia. TRANSYLVANIAN REVIEW OF ADMINISTRATIVE SCIENCES. OCT 2014. Edition 43E. Pages 103-121.

ELBANNA, S. et al. Strategic planning and implementation success in public service organizations evidence from Canada. PUBLIC MANAGEMENT REVIEW. 2016. Volume 18. Edition 7. Pages 1017-1042. DOI 10.1080/14719037.2015.1051576

EREN, V. et al. The Process of Strategic Planning at Universities: A Comparative Study of Selected Private and State Universities. AMME IDARESI DERGISI. JUN 2014. Volume 47. Edition 2. Pages 121-143.

FAVOREU, C. et al. Strategic management in the public sector: a rational, political or collaborative approach?. INTERNATIONAL REVIEW OF ADMINISTRATIVE SCIENCES. SEP 2016. Volume 82. Edition 3. Pages 435453. DOI $10.1177 / 0020852315578410$

GEORGE, B. Does strategic planning work' in public organizations? Insights from Flemish municipalities. PUBLIC MONEY \& MANAGEMENT. 2017. Volume 37. Edition 7. Pages 527-530. DOI 10.1080/09540962.2017.1372116

GEORGE, B. et al. Rational planning and politicians' preferences for spending and reform: replication and extension of a survey experiment. PUBLIC MANAGEMENT REVIEW. 2017. Volume 19. Edition 9. Pages 1251-1271. DOI 10.1080/14719037.2016.1210905

GEORGE, B. et al. Strategic decision quality in Flemish municipalities. PUBLIC MONEY \& MANAGEMENT. JUL 2016. Volume 36. Edition 5. Pages 317-324. DOI 10.1080/09540962.2016.1194073 
GOTHARD, S. ; AUSTIN, M. J. Leadership Succession Planning: Implications for Nonprofit Human Service Organizations. ADMINISTRATION IN SOCIAL WORK. JUN 1 2013. Volume 37. Edition 3. Pages 272-285. DOI $10.1080 / 03643107.2012 .684741$

HAMMERSCHMID, G. ; LOEFFLER, L. The Implementation of Performance Management in European Central Governments: More a North-South than an East-West Divide. NISPACEE JOURNAL OF PUBLIC ADMINISTRATION AND POLICY. DEC 2015. Volume 8. Edition 2. Pages 49-68. DOI 10.1515/nispa-20150008

HARTMAN, S. ; DE ROO, G. Towards managing nonlinear regional development trajectories. ENVIRONMENT AND PLANNING C-GOVERNMENT AND POLICY. 2013. Volume 31. Edition 3. Pages 556-570. DOI 10.1068/c11203r

HINTEA, C. E. et al. Strategic planning and public management reform: the case of Romania. TRANSYLVANIAN REVIEW OF ADMINISTRATIVE SCIENCES. 2015. Pages 30-44.

HOLMAN, N. ; THORNLEY, A. Backlash in the London suburbs: the localstrategic tension in multilevel governance. ENVIRONMENT AND PLANNING CGOVERNMENT AND POLICY. JUN 2015. Volume 33. Edition 3. Pages 496-511. DOI 10.1068/c13135

IGLESIAS ALONSO, A. The Shaping of Local Self-Government and Economic Development through City Strategic Planning: A Case Study. LEX LOCALISJOURNAL OF LOCAL SELF-GOVERNMENT. JUL 2014. Volume 12. Edition 3. Pages 373-391. DOI 10.4335/12.3.373-391(2014)

JACOBSON, W. S. et al. Do Human Resource Departments Act as Strategic Partners? Strategic Human Capital Management Adoption by County Governments. REVIEW OF PUBLIC PERSONNEL ADMINISTRATION. SEP 2014. Volume 34. Edition 3. Pages 289-301. DOI 10.1177/0734371X13507158 JIMENEZ, B. S. Strategic Planning and the Fiscal Performance of City Governments during the Great Recession. AMERICAN REVIEW OF PUBLIC ADMINISTRATION. SEP 2013. Volume 43. Edition 5. Pages 581-601. DOI $10.1177 / 0275074012451051$

JUNG, C. S.; LEE, G. Goals, strategic planning, and performance in government agencies. PUBLIC MANAGEMENT REVIEW. SEP 1 2013. Volume 15. Edition 6. Pages 787-815. DOI 10.1080/14719037.2012.677212

JUNJAN, V. Strategic planning in local governments in Europe: 'where do we go now?'. TRANSYLVANIAN REVIEW OF ADMINISTRATIVE SCIENCES. 2015. Pages 45-54. 
KWON, M. et al. A Theoretical Framework on the Determinants of Strategic Cities: Empirical Results From Florida City Governments. AMERICAN REVIEW OF PUBLIC ADMINISTRATION. JUL 2013. Volume 43. Edition 4. Pages 438459. DOI 10.1177/0275074012445308

LARIONOV, A. V. Areas and forms of regional cooperation in multi-structured (Matreshka-style) regions (Tyumen region, Russia). VOPROSY GOSUDARSTVENNOGO I MUNITSIPALNOGO UPRAVLENIYA-PUBLIC ADMINISTRATION ISSUES. 2015. Edition 5. Pages 82-92.

LEESON, C. ; MORGAN, J. Strategic Planning for Support Services for Children with a Parent or Close Relative in Prison. SOCIAL POLICY \& ADMINISTRATION. DEC 2014. Volume 48. Edition 7. Pages 848-863. DOI 10.1111/spol.12050

LEVASSEUR, K. ; ROUNCE, A. Public policy and operational alignment in light of public service retrenchment - lessons learned from Canada. INTERNATIONAL REVIEW OF ADMINISTRATIVE SCIENCES. SEP 2017. Volume 83. Edition 3. Pages 443-462. DOI 10.1177/0020852315586300

LEVELT, M. ; JANSSEN-JANSEN, L. The Amsterdam Metropolitan Area challenge: opportunities for inclusive coproduction in city-region governance. ENVIRONMENT AND PLANNING C-GOVERNMENT AND POLICY. 2013. Volume 31. Edition 3. Pages 540-555. DOI 10.1068/c11216

LONGO, F. ; ROTOLO, A. Promoting programme gap awareness as a method of effective public strategic management. PUBLIC MANAGEMENT REVIEW. MAR 15 2016. Volume 18. Edition 3. Pages 349-368. DOI $10.1080 / 14719037.2014 .984622$

LUNDBERG, R.; WILLIS, H. H. Deliberative Risk Ranking to Inform Homeland Security Strategic Planning. JOURNAL OF HOMELAND SECURITY AND EMERGENCY MANAGEMENT. APR 2016. Volume 13. Edition 1. Pages 3-33. DOI 10.1515/jhsem-2015-0065

MALEKPOUR, S. et al. Disruptions in strategic infrastructure planning - What do they mean for sustainable development?. ENVIRONMENT AND PLANNING CPOLITICS AND SPACE. NOV 2017. Volume 35. Edition 7. Pages 1285-1303. DOI 10.1177/2399654417690735

MANUEL RUANO, J. Local strategic planning in Spain. A case study. TRANSYLVANIAN REVIEW OF ADMINISTRATIVE SCIENCES. 2015. Pages 71-85.

MARLAND, A. Above and below the line: Strategic communications and media management in Canadian governments. CANADIAN PUBLIC 
ADMINISTRATION-ADMINISTRATION PUBLIQUE DU CANADA. SEP 2017. Volume 60. Edition 3. Pages 417-437. DOI 10.1111/capa.12222

MARLAND, A. Strategic Management of Media Relations: Communications Centralization and Spin in the Government of Canada. CANADIAN PUBLIC POLICY-ANALYSE DE POLITIQUES. MAR 2017. Volume 43. Edition 1. Pages 36-49. DOI 10.3138/cpp.2016-037

MARLIN, D. et al. The Hospital Foundation Strategy and Performance Relationship. NONPROFIT MANAGEMENT \& LEADERSHIP. SUM 2013. Volume 23. Edition 4. Pages 427-441. DOI 10.1002/nml.21073

MATHEWS, J. A. Energizing Industrial Development: The Role of the State in 21st Century Greening Strategies. REVISTA DO SERVICO PUBLICO. OCT 2015. Volume 66. Pages 29-54.

MAZZEI, L. C. et al. High performance sport in Brazil Structure and policies comparison with the international context. GESTION Y POLITICA PUBLICA. 2015. Pages 83-111.

MCMAHON, L.; PHILLIMORE, J. State and Territory Government Strategic Plans: Exercises in Managing, Monitoring and Marketing. AUSTRALIAN JOURNAL OF PUBLIC ADMINISTRATION. DEC 2013. Volume 72. Edition 4. Pages 404-418. DOI 10.1111/1467-8500.12041

MEERMAN, J. R. ; HUYSER, M. Organizational Strategy in a Gentrifying Neighborhood. HUMAN SERVICE ORGANIZATIONS MANAGEMENT LEADERSHIP \& GOVERNANCE. 2014. Volume 38. Edition 5. Pages 448-458. DOI 10.1080/23303131.2014.949334

MINTZBERG, $\mathrm{H}$. The Fall and Rise of Strategic Planning. Harvard Business Review, (January-February): 107-114, 1994.

MINTZBERG, H.; Waters, James A. Of Strategies, Deliberate and Emergent. Strategic Management Journal, Vol. 6, No. 3. (Jul. - Sep., 1985), p. 257-272. Available on http://links.jstor.org/sici?sici=01432095\%28198507\%2F09\%296\%3A3\%3C257\%3AOSDAE\%3E2.0.CO\%3B2-T . Access on 20 dec. 2017.

OLGA, S. I. Problems of strategic planning in municipalities by the example of Khabarovsk and Vladivostok. VOPROSY GOSUDARSTVENNOGO I MUNITSIPALNOGO UPRAVLENIYA-PUBLIC ADMINISTRATION ISSUES. 2015. Edition 4. Pages 119-134.

PASHA, O.; POISTER, T. H. Exploring the Change in Strategy Formulation and Performance Measurement Practices Under Turbulence. PUBLIC 
PERFORMANCE \& MANAGEMENT REVIEW. 2017. Volume 40. Edition 3. Pages 504-528. DOI 10.1080/15309576.2016.1276843

PERCOCO, M. Strategic planning and institutional collective action in Italian cities. PUBLIC MANAGEMENT REVIEW. JAN 2 2016. Volume 18. Edition 1. Pages 139-158. DOI 10.1080/14719037.2014.969758

PERNSTEINER, A. et al. Budget repair or budget spectacle? The passage of Wisconsin's Act 10. PUBLIC MONEY \& MANAGEMENT. 2016. Volume 36. Edition 7. Pages 507-514. DOI 10.1080/09540962.2016.1237144

PETREA, R. et al. Place branding as efficient management tool for local government. TRANSYLVANIAN REVIEW OF ADMINISTRATIVE SCIENCES. DEC 2013. Pages 124-140.

POISTER, T. H. et al. Strategy formulation and performance evidence from local public Transit Agencies. PUBLIC PERFORMANCE \& MANAGEMENT REVIEW. JUN 2013. Volume 36. Edition 4. Pages 585-615. DOI 10.2753/PMR15309576360405

PROFIROIU, M. et al. Performance analysis of the Romanian public administration. TRANSYLVANIAN REVIEW OF ADMINISTRATIVE SCIENCES. OCT 2013. Edition 40E. Pages 183-200.

RABOVSKY, T. M. Using Data to Manage for Performance at Public Universities. PUBLIC ADMINISTRATION REVIEW. MAR 2014. Volume 74. Edition 2. Pages 260-U231. DOI 10.1111/puar.12185

RAUDLA, R. Pitfalls of Contracting for Policy Advice: Preparing Performance Budgeting Reform in Estonia. GOVERNANCE-AN INTERNATIONAL JOURNAL OF POLICY ADMINISTRATION AND INSTITUTIONS. OCT 2013. Volume 26. Edition 4. Pages 605-629. DOI 10.1111/gove.12006

RAUDLA, R. et al. Fiscal Crisis and Expenditure Cuts: The Influence of Public Management Practices on Cutback Strategies in Europe. AMERICAN REVIEW OF PUBLIC ADMINISTRATION. APR 2017. Volume 47. Edition 3. Pages 376394. DOI 10.1177/0275074016661029

RHODES, R. A. W.. Political anthropology and civil service reform: prospects and limits. POLICY AND POLITICS. OCT 2013. Volume 41. Edition 4. Pages 481496. DOI 10.1332/030557312X655684

RYAN, R. ; HASTINGS, C. Missed opportunities for democratic engagement: the adoption of community indicators in local government. ASIA PACIFIC JOURNAL OF PUBLIC ADMINISTRATION. 2015. Volume 37. Edition 1. Pages 33-43. DOI $10.1080 / 23276665.2015 .1018376$ 
SANSOM, G. Reframing the role of Australian mayors: an update and rejoinder to Grant, Dollery and Kortt (2016). LOCAL GOVERNMENT STUDIES. DEC 2016. Volume 42. Edition 6. Pages 1047-1059. DOI 10.1080/03003930.2016.1228564 SCHERHAG, C. ; BOENIGK, S. Different or Equal Treatment? Donor Priority Strategy and Fundraising Performance Assessed by a Propensity Score Matching Study. NONPROFIT MANAGEMENT \& LEADERSHIP. SUM 2013. Volume 23. Edition 4. Pages 443-472. DOI 10.1002/nml.21074

STAPLES, W. ; DALRYMPLE, J. Construction Procurement and State Government Strategy: Aligned or Disconnected?. AUSTRALIAN JOURNAL OF PUBLIC ADMINISTRATION. JUN 2016. Volume 75. Edition 2. Pages 222-235. DOI 10.1111/1467-8500.12114

SZABO, S. et al. Linking objective-oriented transparency to political leadership and strategic planning. TRANSYLVANIAN REVIEW OF ADMINISTRATIVE SCIENCES. 2016. Pages 75-90.

SZTANDO, A. Does the strategic planning of local development result from the motives indicated in literature? Contemporary motivation of Polish small towns' authorities for strategic planning of local development. TRANSYLVANIAN REVIEW OF ADMINISTRATIVE SCIENCES. JUN 2017. Edition 51E. Pages 106-122. DOI 10.24193/tras.51E.7

UNAL, M. C. How Far Can the Public Organizations Be Strategically Managed? Strategy as a Term, Strategic Planning/Management and its CompatibilityConflict in the Public Sector. AMME IDARESI DERGISI. JUN 2013. Volume 46. Edition 2. Pages 25-43.

VAN RAVENSWAY, J. ; HAMLIN, R. E. Strategic planning in US municipalities. TRANSYLVANIAN REVIEW OF ADMINISTRATIVE SCIENCES. 2015. Pages 55-70.

VLADIMIR, Y. N. Governance for results: on the preparing of draft federal law on fundamentals of public administration in the Russian Federation. VOPROSY GOSUDARSTVENNOGO I MUNITSIPALNOGO UPRAVLENIYA-PUBLIC ADMINISTRATION ISSUES. 2016. Edition 1. Pages 129-148.

VULFOVICH, R. M. Agglomerations as strategic actors in a globalizing world. VOPROSY GOSUDARSTVENNOGO I MUNITSIPALNOGO UPRAVLENIYAPUBLIC ADMINISTRATION ISSUES. 2016. Edition 5. Pages 119-137. 